produces intense international hand-wringing. Danger does lurk there, largely owing to Pakistan's political crisis and reluctance to formalize the territorial status quo with India. Stimuli for conflict emerge from Pakistan; competitive logic and political imperatives may lead both states to brinkmanship. As suggested in the chapters on India, by Rajesh Rajagopalan, and on Pakistan, by Feroz Hassan Khan and Peter Lavoy, both countries recognize that nuclear weapons make a war between them unwinnable. Yet they remain unable to transform this recognition into a confident peace that would empower Pakistan's civilian leaders to press the army and intelligence services to concentrate on internal security rather than nurturing low-intensity violence in India and Afghanistan.

The comparative advantage of The Long Shadow emanates from the chapters on Japan, China, South Korea and North Korea. Paradoxically, in northeast Asia the threats of direct conflict are low, but concerns about the nuclear future are high. This suggests the political, more than the specifically military, importance of these weapons.

Michael Green and Katsuhisa Furukawa write in the book that nuclear weapons are increasingly present in Japanese thinking, but not as war-fighting instruments or protection against existential threat. "Rather, it is the specter of political and strategic entropy that would be associated with a collapse of the US extended deterrence commitment that is animating strategic thinking in Japan.” North Korea's bomb and improved Chinese capabilities reopen "the old question of whether the United States would protect Japan even at the risk of inviting nuclear strikes against US cities". Some Japanese strategic thinkers worry that the United States might "conclude a bilateral arms control agreement with Beijing that endorses protection of Chinese limited nuclear strike capability against the US". They fear this would decouple the United States from Japan.

Kang Choi and Joon-Sung Park describe how South Koreans have an "excessive fear of nuclear threat" combined with a "fear of abandonment" by the United States, and its opposite, "fear of entrapment". They argue that South Korea's fear of abandonment "could soar if the United States tacitly accepted North Korea's nuclear weapon status". Conversely, the fear of entrapment "would linger as long as the public believes that a US military strike on North Korea is possible".

Doubts about the credibility of extended deterrence were much greater during the cold war, as Green and Furukawa and Choi and Park document. Still, policy-makers in
Washington, Tokyo, Seoul and Beijing must undertake concerted diplomacy to instil political-strategic confidence in the region in ways that reduce rather than raise the salience of nuclear weapons.

The Long Shadow offers useful guidance to this end. None of the authors urges US retrenchment from the region or rethinking of Japanese, South Korean or Taiwanese nuclear abstinence. Acquisition of nuclear weapons by these countries would only exacerbate insecurity and reduce US commitments to act to defend peace and stability there. Instead, greater effort must be made to enhance the transparency of intentions and capabilities, bolster conventional deterrence and foster unity in dealing with North Korea.

Leaders in the United States and China together hold a key. China will not become more cooperative and transparent and limit its strategic build-up if the United States does not clarify that it is prepared to accept China's nuclear deterrent. This would mean limiting missile defences and certain nonnuclear strike capabilities. Sino-American strategic accommodation need not devalue the US extended deterrent, as some in Japan may fear. As long as nuclear weapons remain, the United States will extend its deterrence umbrella to its allies. To reassure Japan of this, leaders in Washington, Beijing and Tokyo must undertake more forthright strategic dialogues. Framing such dialogue with an explicit objective of creating conditions for incremental, verifiable steps towards nuclear disarmament would add an important Asian dimension to the global effort to live up to the promise made in the 1968 Nuclear Nonproliferation Treaty, the future of which has come into question.

The shadow in this volume's title refers to the chastening threat of nuclear war. The complexity and particularity of the nuclear story in each country surveyed reminds us that the people responsible for preventing the darkness of nuclear war would benefit from the light that careful scholarship can provide. The illumination offered in The Long Shadow should be welcomed.

George Perkovich is vice-president for studies at the Carnegie Endowment for International Peace and is a co-editor of the book Abolishing Nuclear Weapons: A Debate.

e-mail: gperkovich@carnegieendowment.org

\title{
Pugwash, nukes and peace
}

After years of backsliding on nuclear-weapons proliferation by the world's superpowers, President Barack Obama has stated that he intends to "make the goal of eliminating all nuclear weapons a central element" in nuclear policy. His recently appointed chief science adviser, physicist John Holdren, spent ten years as chairman of the executive committee for the Pugwash Conferences on Science and World Affairs, the peripatetic annual meeting of scientists and statesmen to discuss ways to control nuclear weapons. It is named after the Canadian village of Pugwash, Nova Scotia, where its first conference was held
The Strangest Dream Film directed by Eric Bednarski Produced by the National Film Board of Canada

Joseph Rotblat: A Man of Conscience in the Nuclear Age by Martin Underwood Sussex Academic Press: 2009. 144 pp. $£ 17.95$

Professor Pugwash, The Man Who Fought Nukes: The Life of Sir Joseph Rotblat

by Kit Hill

Ryelands: 2008.80 pp. $£ 8.99$ the 1955 Russell-Einstein Manifesto against nuclear weapons, which gave rise to the first Pugwash Conference at the height of the cold war in 1957. Rotblat dedicated more than half a century to the fight to abolish nuclear weapons. In 1995, he and the Pugwash organization shared the Nobel Peace Prize.

Two edited collections on Rotblat were published soon after his death in 2005 at the age of 96 . As yet there is no substantial biography, although one is being prepared by the writer Andrew Brown. Now, Rotblat is the focus of The Strangest Dream - a Canadian documentary film (http://tinyurl.com/ under the sponsorship of a wealthy Canadian philanthropist, Cyrus Eaton.

The late Joseph Rotblat would have been heartened by these recent political developments. Rotblat was the youngest signatory of cnehl3) made to celebrate the centenary of his birth - which is intelligent, vivid and all the more powerful for its restraint; and the subject of two brief but interesting books - Martin Underwood's Joseph Rotblat and Kit Hill's 
Professor Pugwash, The Man Who Fought Nukes. Both authors are physicists who knew Rotblat personally. Hill is a long-standing collaborator in British Pugwash, as mentioned in the foreword by UK Astronomer Royal Martin Rees. Underwood worked as a postdoc with Rotblat on the linear accelerator at St Bartholomew's Hospital in London. Their books aim to introduce Rotblat's life and work to distinct readerships - with uneven results. Ironically, it is the director of the film, Eric Bednarski, who, despite having missed meeting his subject in the flesh, brings Rotblat alive.

Rotblat's first words on screen express his attitude to his science. Speaking in the precise, Polish-accented English he learned in wartime Britain in his thirties, he says: "If my work is going to be applied, I would like myself to decide how it will be applied." Not for Rotblat the seductive idea that scientists have no responsibility for the uses to which their discoveries are put. Ethics were as important to him as experiments.

Born in 1908 into a religious Jewish family in Warsaw, reduced to penury by the First World War, Rotblat was forced to become an electrician after leaving school. Eventually he entered academic physics through evening school, worked under a professor trained by Marie Curie and, in mid-1939, left Poland for the University of Liverpool, UK, to conduct nuclear-physics research under James Chadwick, discoverer of the neutron. Atomic fission had just been discovered in Germany, and even before leaving Poland, Rotblat had privately visualized that fission could lead to an atomic bomb. Wrestling with his conscience - like Albert Einstein in 1939 - and leaving behind his Polish wife, who was eventually sent to a Nazi death camp, he decided that he must work on the bomb in case the Germans built one first and won the war. Chadwick, at first reticent to discuss such a sensitive subject with an 'alien', however friendly and able, finally got permission to bring Rotblat to join his team at the Atomic Research Laboratory in Los Alamos, New Mexico - the Manhattan project.

Rotblat was the sole physicist to leave Los Alamos on grounds of conscience before the atomic bomb was dropped on Japan in August 1945. At a dinner party in 1944, he learned from the US army general in charge of the Manhattan project that the real target was Russia, and from Chadwick that Nazi Germany had abandoned its rival project. He resigned immediately and returned to the

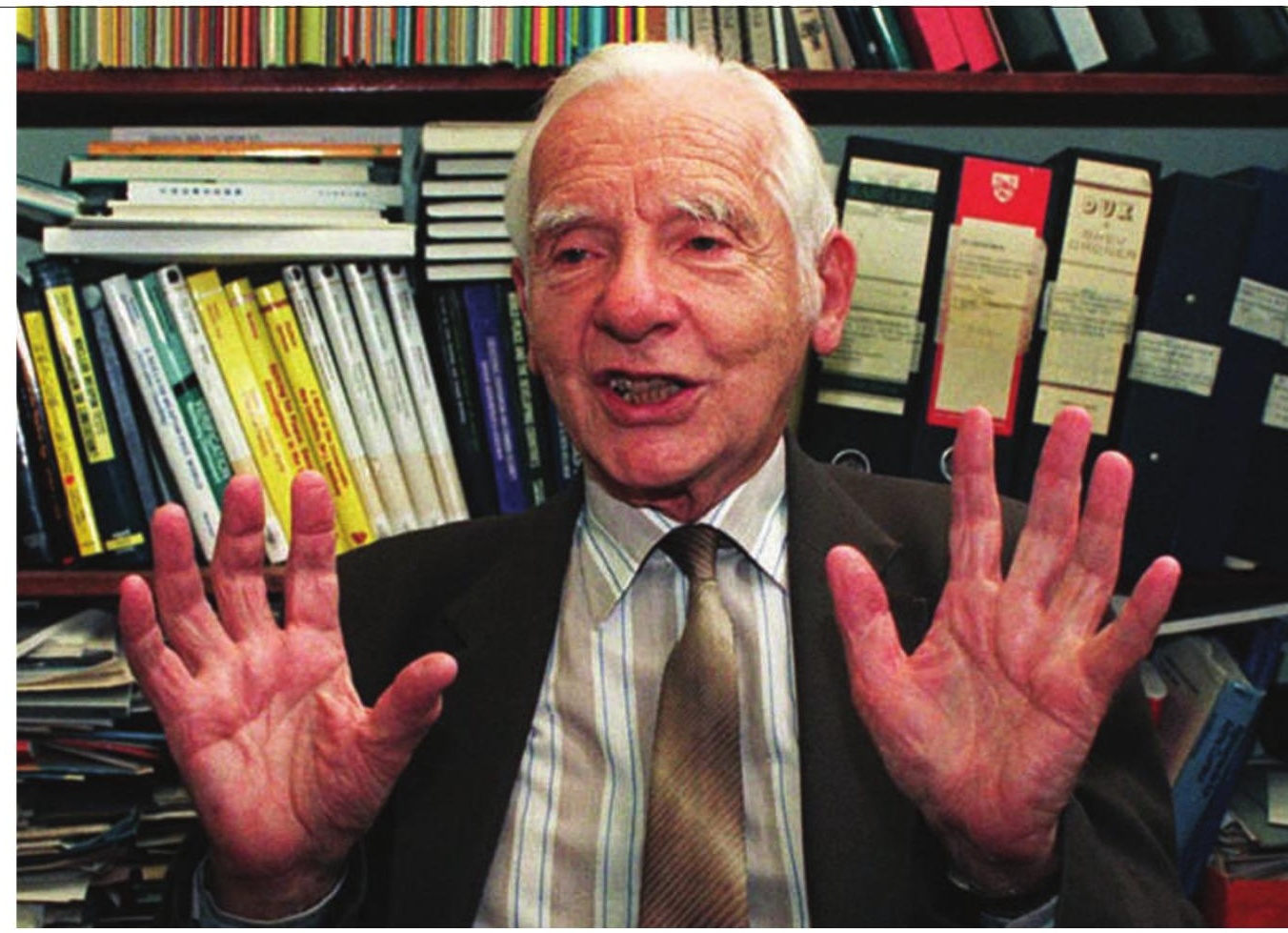

Joseph Rotblat won a Nobel prize for his work on nuclear disarmament with the Pugwash organization.

United Kingdom under a cloud of suspicion from US intelligence that he was a spy for the Soviet Union. A trunk of his papers mysteriously disappeared in transit from Los Alamos, presumably into the archives of the Federal Bureau of Investigation. Some other bombmaking physicists felt qualms in 1945 and even protested to the authorities, but only Rotblat had the "courage" to risk his career for his convictions, observes Pakistan Pugwash nuclear physicist Pervez Hoodbhoy in the film. "He was not the kind of man to be told what to think," says Rotblat's Polish niece Halina Sand.

This is mainly why Pugwash was effective during the cold war. The first conference was attended by one lawyer and 21 scientists from the United States, the Soviet Union, the United Kingdom, China, France, Poland, Australia, Japan, Austria and Canada. Despite pressure from governments, Rotblat and the Pugwash Conferences refused to toe official lines. Instead, participants - whether Soviet scientists or statesmen such as former US defence secretary Robert McNamara - spoke as individuals. The meetings were private, but not secret, and held without the presence of the media. Formal speeches were generally eschewed; discussions took place around a table and informally, with the agreement that contributions would not be publicly attributed to individuals, so they could speak relatively freely. The result, notes Underwood, is that Pugwash was instrumental in achieving the signing of the Partial Test Ban Treaty in 1963 and, in 1972, both the Biological Weapons Convention and the Anti-Ballistic Missile Treaty. It also helped mediate between Moscow and Washington DC during the Cuban missile crisis of 1962, and established strong links with the Soviet leader Mikhail Gorbachev, who admired Rotblat, at the time of Gorbachev's arms negotiations with US President Ronald Reagan in the 1980s.

Underwood emphasizes politics more than science, and writes conventionally. Hill is more impressionistic and quirky, with the science explained at a very basic level in boxes. Both books contain errors; for example, Marie Curie's second Nobel prize was not for work on "artificial radioactivity" done with her daughter, as claimed by Hill. But it is nice to know from his book that Captain Pugwash, the British comic-strip pirate created in 1950 - whose fame initially made Rotblat suspect that Eaton's offer of sponsorship was a hoax - later sent the Pugwash Conferences a congratulatory scroll.

Andrew Robinson is a visiting fellow of Wolfson College, University of Cambridge, Cambridge CB3 9BB, UK. His book Einstein: A Hundred Years of Relativity contains material by Joseph Rotblat on Einstein's quest for global peace.

e-mail:ar471@cam.ac.uk 